\title{
Effect of environmental pollution on oxidative stress in African catfish (Clarias heterobranchus)
}

\author{
Achuba Fidelis Ifeakachuku ${ }^{1}$, Ebokaiwe Peter ${ }^{1}$, Peretiemo-Clarke Beatrice O. $^{2}$ \\ ${ }^{1}$ Department of Biochemistry, Delta State University, PMBI Abraka Nigeria \\ ${ }^{2}$ Department of Chemistry, Delta State University, PMBI Abraka Nigeria
}

Email address:

achubabch@yahoo.Com (Achuba F. I.)

To cite this article:

Achuba Fidelis Ifeakachuku., Ebokaiwe Peter, Peretiemo-Clarke Beatrice O.. Effect of Environmental Pollution on Oxidative Stress in African Catfish (Clarias heterobranchus). International Journal of Environmental Monitoring and Analysis. Vol. 2, No. 6, 2014, pp. $297-301$. doi: 10.11648/j.ijema.20140206.11

\begin{abstract}
Oxidative stress biomarkers: levels of Lipid peroxidation as well as changes in catalase and superoxide dismutase activities were investigated in tissues of African catfish, $\mathrm{C}$ heterobranchus inhabiting Warri River. Data were compared to those of reference hatchery. Lipid peroxidation products in fish from the midstream and downstream parts of the river were significantly $(\mathrm{P}<0.05)$ different from fish collected from upstream. Similarly, lipid peroxidation products in tissues of fish from midstream and downstream parts of the river were significantly $(\mathrm{P}<0.05)$ different from fish in the reference hatchery. No significant difference was observed between fish in the upper part of the river and those from reference hatchery. Similar to lipid peroxidation, the activities of antioxidant enzymes, catalase and superoxde dismutases (SOD) were significantly $(\mathrm{P}<0.05)$ different in fish from midstream and down stream parts of the river compared to fish collected from upstream and reference hatchery. The elevated levels of lipid peroxidation, catalase and superoxide dismutase activities in all tissues examined in $\mathrm{C}$ heterobranchus could be a reflection of oxidative stress on the fish.
\end{abstract}

Keywords: Catalase Activity, Fish, Lipid Peroxidation, Superoxide Dismutase Activity

\section{Introduction}

The River Warri is an important river in the Niger Delta of southern Nigeria. The economic importance of the river is predicated on its rich biota (Egborge 1986; Egborge and Tawarri 1987; Opute 1991, Tetsola and Egborge 1991; Ikomi 1995) that provide various kinds of fishes for human consumption, means of inland water transport for most communities in the region and the site of a large port at Forcados (Ikomi 2000). However, the river is highly polluted due to the presence of oil / petrochemical complex (Egborge 1991), enormous oil exploration activities in Warri and its environs and discharge of domestic and other industrial effluent into the river (Egborge, 1991).

The extent of pollution of Warri Rivers has been monitored by an array of the scientific communities (Atuma and Egborge, 1986 Egborge 1991; 1994)culminating in changes in water quality indices (Egborge and Benka - Coker, 1986; Ikomi 1993; 2000) and bioconcentratin of trace metals in fish (Kakulu et al 1997; Ezemonye 1992; Agada, 1994).

Fish in natural environment are often exposed to a variety of stressors that can adversely affect their health. Thus, there is a need to develop tools to assess environmental related stress in fish (Afonso et al 2003). Some of the biondicators of stress in fish include increase in levels of plasma cortisol, glucose and lactate (Barton and Iwama, 1991); induction of heat shock protein (Iwama et al 1999); glucose and drug metabolizing enzymes (Isamah and Asagba, 2004).

The induction of oxidative stress in fish by polluted environment is well documented (Bainy et al 1996; DiGuilio et al 1989; Hai 1997). This study reports on oxidative stress on Clarias heterobranchus from Warri River in southern Nigeria.

\section{Materials and Method}

\subsection{Study Area}

The study area is Warri River. It is located between latitude $5^{0} 21^{1}-6^{0} .00^{1} \mathrm{~N}$ and longitude $5^{0} 25^{1} \mathrm{E}$. The river took its source at Utagba - Uno and flow towards south west through Eziokpor, Amai, Otorho - Abraka, Warri and emptying into the sea at Forcados (Tetsola and Egborge, 1991). 
The fishes, Clarias heterobranchus were obtained from the upper, middle and near the lower course of the Warri River between August and September, 2004. The fishes were caught using instrument made locally. They were transported alive to the laboratory and allowed to stabilize for one week before they were dissected to extract organs and tissues of interest. Similar fish of comparable size were obtained from a commercial fish pond located in Abraka and were used as control. The fishes were sorted and duly identified by the Department of Zoology, Delta State University, Abraka, Nigeria.

A total of 30 samples of mature size-matched male $\mathrm{C}$ heterobranchus (average wet weight $340+5 \mathrm{~g}$ and average wet length $38.7 \pm 3.2 \mathrm{~cm}$ ) were collected from each site. Males were chosen for this study in order to be sex specific since biomarkers have been found to be sex related (Afonso et al 2003). All the reagents used were of analytical grade.

\subsection{Methods}

\subsubsection{Preparation of Extract for the Determination of Lipid Peroxidation}

Of the isolated organs $0.5 \mathrm{~g}$ were separated and homogenized with $10 \mathrm{ml}$ of ice-cold $0.05 \mathrm{M}$ phosphate butter pH 7.0 containing $1 \%(\mathrm{w} / \mathrm{v})$ Triton X-100, excess butylated hydroxyl toluene (BHT) and a few crystals of protease inhibitor, phenylmethylsulfonyl fluoride using an MSE blender immersed in ice. Triton X-100 solubilizes membraneenclosed organells while BHT prevents in vitro oxidation of lipid during homogenization. The extract was centrifuged at $7000 \mathrm{~g}$ for $20 \mathrm{~min}\left(4^{0} \mathrm{C}\right)$. The supernatant $\left(\mathrm{S}_{1}\right)$ was used for the determination of lipid peroxidation by the method of Hunter et al (1963) as modified by Gutteridge and Wilkins (1982).

\subsubsection{Extraction and Assay of Catalase}

Catalase was measured with a similar $\left(\mathrm{S}_{1}\right)$ fraction after addition of $1 \%(\mathrm{~V} / \mathrm{V})$ of ethanol and incubation at $4^{0} \mathrm{C}$ for 15 $\mathrm{min}$. This treatment is reported to reverse the inactivation of catalase, which takes place, by the formation of compound 11 (Cohen et al, 1970). Catalase activity was determined according to Beers and Sizer (1952) by measuring the decrease in the $\mathrm{H}_{2} \mathrm{O}_{2}$ concentration, at an absorbance of 240nm. An extinction coefficient for $\mathrm{H}_{2} \mathrm{O}_{2}$ of $40 \mathrm{M}^{-1} \mathrm{~cm}^{-1}$ (Abei, 1974) was used in the calculation.

\subsubsection{Extraction and Assay of Superoxide Dismutase}

An aliquot of the supernatant $\left(\mathrm{S}_{1}\right)$ was precipitated on ice with 0.30 volume of chloroform/ methanol $(3: 5 \mathrm{v} / \mathrm{v})$ stirred for $20 \mathrm{~min}$ and centrifuged at $7000 \mathrm{~g}$ at $4^{0} \mathrm{C}$. The obtained supernatant $\left(\mathrm{S}_{2}\right)$ was used for the assay of superoxide dismutase (SOD) activity, which was based on its ability to inhibit the oxidation of epinephrine by superoxide anion (Aksnes and Njaa, 1981). One unit of superoxide dismutase activity is defined as the amount of enzyme required for $50 \%$ inhibition of the oxidation of epinephrine to adrenochrome at 480nm per min (Misra and Fridovich, 1972). Manganese dependent SOD was analyzed in the presence of $1 \mathrm{mM} \mathrm{NaCN}$ to suppress $\mathrm{Cu}-\mathrm{ZnSOD}$ activity and the cytosolic $\mathrm{Cu}-\mathrm{ZnSOD}$ activity was determined as the difference between total and cyanide - sensitive enzyme activity (Crapo et al, 1978). The enzyme activities were assayed with an SP 1800 UV/VIS Spectrophotometer.

\section{Statistical Analysis}

All the results were expressed as means \pm SE and all data were analyzed using Analysis of variance (ANOVA). Significant difference between the control and polluted sites means were determined at 5\% $(\mathrm{P}<0.05)$ confidence level using Duncan's Multiple Range Test.

\section{Results and Discussion}

Oxidative stress biomarkers were studied in the muscle, liver, kidney, heart and intestinal tract of African catfish, $\mathrm{C}$ heterobranchus from Warri River and comparable fish from a local fish hatchery which served as control. Oxidative stress biomarkers were lipid peroxidation, catalase and superoxide dismutase activities. The results showed that lipid peroxidation was significantly $(\mathrm{P}<0.05)$ higher in all the organs/tissues from Warri River compared to fish from reference hatchery (table 1). Similarly, the level of lipid peroxidation products in fishes collected in the lower sector of the river were significantly $(\mathrm{P}<0.05)$ higher than those of fishes collected from the upper sector (table 2). This observation is consistent with the report of Fatima et al (2000) and Achuba (2002).

Table 1. Levels of lipid peroxidation in organs of catfish from Warri River and control. Level of lipid peroxidation $\left(\mu \mathrm{molml}^{-1}\right)$.

\begin{tabular}{|c|c|c|c|c|}
\hline Organ/tissue & Control & Upper & Middle & Lower \\
\hline Liver & $6.6 \pm 2.21^{a}$ & $6.7 \pm 1.4^{\mathrm{a}}$ & $10.5 \pm 2.5^{a}$ & $13.6 \pm 1.8 \mathrm{a}$ \\
\hline Gills & $3.38 \pm 0.28^{b}$ & $3.21 \pm 1.1^{\mathrm{b}}$ & $8.80 \pm 1.5^{\mathrm{a}}$ & $16.7 \pm 2.3^{\mathrm{c}}$ \\
\hline Muscle & $4.38+0.34^{\mathrm{v}}$ & $3.86 \pm 1.3^{\mathrm{v}}$ & $5.32 \pm 1.2^{\mathrm{U}}$ & $5.89 \pm 1.6^{\mathrm{U}}$ \\
\hline Brain & $6.56 \pm 0.42^{a}$ & $5.11+2.1^{\mathrm{v}}$ & $23.2 \pm 1.5$ & $26.14 \pm 1.5^{\circ}$ \\
\hline Kidney & $4.49 \pm 078^{0}$ & $4.12 \pm 0.3^{\mathrm{O}}$ & $6.3 \pm 1.4^{0}$ & $9.13+2.2^{0}$ \\
\hline $\begin{array}{l}\text { Intestinal } \\
\text { tract }\end{array}$ & $11.13 \pm 0.48^{\mathrm{c}}$ & $8.11 \pm 1.8^{\mathrm{c}}$ & $17.21 \pm 1.5^{\mathrm{c}}$ & $24.4 \pm 1.6^{\mathrm{c}}$ \\
\hline Heart & $4.38+0.83^{\mathrm{v}}$ & $5.13+1.6^{v}$ & $7.55 \pm 1.7^{v}$ & $12.6 \pm 1.9^{a}$ \\
\hline
\end{tabular}

Values are means $\pm \mathrm{SE}$ of determinations for five fishes. Mean with different superscript letters in the same row are significantly different at $\mathrm{P}<0.05$

Lipid peroxidation has been used as a measure of xenobiotic-induced oxidative stress in fish and these include lipid perroxidation in Atlantic croacks (Thomas et al 1993); Indian catfish (Parihar and Dubey, 1995) and Channel catfish (DiGuilio et al 1993). Moreover, increase in lipid peroxidation has been reported in fish exposed to polluted environment (Munkittrick et al 1998; 2000. Fatima et al 2000).Besides acting as a mediator in oxidative stress, higher levels of lipid peroxidation products can adversely affects cellular functions (Munkittrick et al 1998; 2000) and adduct with proteins and DNA which may predispose the cell to mutagenesis and carcinogenesis (Bailey et al, 1992; 1996).

The activities of superoxide dismutase and catalase were 
higher in fish from Warri River relative to fish from reference hatchery (Table 2 and 3). Like lipid peroxidation, the activities of these antioxidant enzymes were higher in fishes collected from downstream compared to those obtained from upstream. This result is consistent with earlier observations (Achuba 2002; Fatima et al 2000; Livingstone, 2001).A Previous report indicated that in response to increased levels of reactive oxygen species and oxidative damage, cells will usually increase the accumulation of a number of enzymatic antioxidants (Downs et al, 2002). Cu/ZnSOD and MnSOD are some of the markers of cellular responses to increased reactive species and have been found to accumulate in response to oxidative stress (Downs et al 2002). Similar responses have been reported in aquatic species in an environment with a history of exposure to xenobiotic causing oxidative stress (Rodriquez-Ariza et al 1995; Otto and Moon, 1996). Exposure to xerobiotics has been reported to greatly induce production of reactive oxygen species (Gokaoyr and Husay 1998; Livingstone 2001).

Table 2. Superoxide dismutase activities in organs of catfish from Warri River and control. Superoxide dismutase activities (Unitsg ${ }^{I}$ wet $\left.w t\right)$.

\begin{tabular}{|c|c|c|c|c|}
\hline Organ & Total S & & $\mathrm{Cu} / 2 \mathrm{nSOD}$ & MnSOD \\
\hline \multirow{4}{*}{ Liver } & Control & $669.3 \pm 30^{a}$ & $568.9 \pm 24^{a}$ & $100.4+13^{a}$ \\
\hline & Upper & $652.8 \pm 60^{\mathrm{a}}$ & $556.1+22^{\mathrm{a}}$ & $96.8+\overline{33}^{\mathrm{a}}$ \\
\hline & Middle & $875.9 \pm 29 \mathrm{c}$ & $744.6+25 \mathrm{c}$ & $131.4+40 \mathrm{c}$ \\
\hline & Lower & $946.1 \pm 41 \mathrm{c}$ & $798.2 \pm 35^{\mathrm{c}}$ & $146.7 \pm 50 \mathrm{c}$ \\
\hline \multirow{4}{*}{ Gills } & Control & $437.4 \pm 60^{\mathrm{a}}$ & $374.0 \pm 50^{a}$ & $63.4 \pm 10 \mathrm{a}$ \\
\hline & Upper & $421+3.100 \mathrm{a}$ & $360.1 \pm 63^{a}$ & $61.3+32^{\mathrm{a}}$ \\
\hline & Middle & $591.1 \pm 101^{\mathrm{c}}$ & $508.6 \pm 84^{\mathrm{c}}$ & $82.5 \pm 17^{\mathrm{c}}$ \\
\hline & Lower & $682.6 \pm 35^{c}$ & $591.1 \pm 63^{\mathrm{c}}$ & $913 \pm 33^{\mathrm{c}}$ \\
\hline \multirow{4}{*}{ Muscle } & Control & $247.4+35^{a}$ & $207+80$ & $39.0+40^{a}$ \\
\hline & Upper & $251.5 \pm 30^{\mathrm{a}}$ & $201 \pm 70^{a}$ & $48.3 \pm 65^{\mathrm{a}}$ \\
\hline & Middle & $343.3 \pm 29 \mathrm{c}$ & $288 \pm 24^{\mathrm{c}}$ & $54.9 \pm 50 \mathrm{c}$ \\
\hline & Lower & $351.1 \pm 53{ }^{\mathrm{c}}$ & $292+12{ }^{c}$ & $58.8+34{ }^{\mathrm{c}}$ \\
\hline \multirow{4}{*}{ Brain } & Control & $328.7+135^{\mathrm{a}}$ & $269.5+111^{a}$ & $59.2+24^{a}$ \\
\hline & Upper & $316.5+77^{\mathrm{a}}$ & $258.1+126^{a}$ & $58.2+33^{\mathrm{a}}$ \\
\hline & Middle & $467.2+169^{c}$ & $383.1+139^{c}$ & $84.1+30^{c}$ \\
\hline & Lower & $482+121^{\mathrm{c}}$ & $398.3+101^{\mathrm{c}}$ & $84.8+22^{c}$ \\
\hline \multirow{4}{*}{ Kidney } & Control & $740.2+145_{b}^{a}$ & $621.8+122^{a}$ & $118.4+23^{a}$ \\
\hline & Upper & $673.3+102^{b}$ & $578.3+89^{b}$ & $103+44^{b}$ \\
\hline & Middle & $839.3+222^{c}$ & $705.0+10.6^{\mathrm{c}}$ & $134.3+36^{\mathrm{c}}$ \\
\hline & Lower & $878.8+156^{c}$ & $746.8+117^{c}$ & $138.0+22^{c}$ \\
\hline \multirow{4}{*}{$\begin{array}{l}\text { Intestinal } \\
\text { tract }\end{array}$} & Control & $217.4+33^{a}$ & $180.5+27^{a}$ & $36.95+60^{a}$ \\
\hline & Upper & $214.6+26^{a}$ & $173.4 \pm 18{ }^{\mathrm{a}}$ & $41.30 \pm 11^{\mathrm{a}}$ \\
\hline & Middle & $371.8+35^{c}$ & $308.6+29 \mathrm{c}$ & $63.21+60 \mathrm{c}$ \\
\hline & Lower & $383.9 \pm 77^{\mathrm{c}}$ & $311.7+38^{c}$ & $71.11+35^{\mathrm{c}}$ \\
\hline \multirow{4}{*}{ Heart } & Control & $1589 . \overline{1}+38^{a}$ & $1318 . \overline{9} 5+32^{a}$ & $270.1 \overline{5} \pm 60^{\mathrm{a}}$ \\
\hline & Upper & $1504.0 \pm 44 \mathrm{~b}$ & $1238.0 \pm 66^{\mathrm{b}}$ & $266.1 \pm 80{ }^{\mathrm{a}}$ \\
\hline & Middle & $3258.5+57^{\mathrm{C}}$ & $2704.55+47^{\mathrm{c}}$ & $553 \pm 100 \mathrm{c}$ \\
\hline & Lower & $3867.4+67^{\mathrm{c}}$ & $3285.6 \pm 101{ }^{c}$ & $581 \pm 110^{\mathrm{c}}$ \\
\hline
\end{tabular}

Values as means \pm SE of determinations from five fishes. Mean with different superscript letters in the same row are significantly different at $\mathrm{P}<$ 0.05 .

Previous reports have implicated SOD and catalase as working in tandem to dismutate oxygen radicals at physiological conditions (Achuba and Osakwe 2003). SOD converts superoxide anions to hydrogen peroxide which is broken down to oxygen and water by catalase (Voet and Voet, 1990). It is, therefore, no surprise for the observed increase in catalase activities in all the studied organs (Table 2).
Pollution-induced increase in the activity of catalase had been reported earliar by some investigators (RodriquezAriaze et al 1993; Hasspieler et al, 1994, Isamah et al, 2000).

In generally, total superoxide dismutase and catalase activities have been reported as a potent mediator in chemical stress in fish (Achuba and Osakwe, 2003). Simirnoff (1993) found that an increase in the capacity of antioxidant defense in response to an increased level of reactive oxygen represents an indirect measure of oxidative stress. Fatima et al (2003) reported a significant increase in extra-hepatic oxidative stress in tissues such as kidney and gill of fish exposed to pulp and paper mill effluents. The higher value of antioxidant enzyme activities in fishes collected from the middle sector of the river relative to fish from reference hatchery and from the upper sector predicts that the fish collected in these regions of Warri Rivers are experiencing oxidative stress. The difference in the activity of these enzymes is a function of its environment and this has been established by Izokun-Etoibhio et al (1990).

It is relevant to conclude that a polluted environment could result in increase lipid peroxidation, superoxide dismutase and catalase activities in tissues of $C$ heterobranchus. On the whole, the results presented suggest that environmental pollution could act as a mediator in the induction of oxidative stress in Cheterobranchus.

Table 3. Catalase activities in organs of catfish from Warri River and control. Catalase activities ( $\mu$ molmin ${ }^{-1} \mathrm{~g}^{-1}$ tissue).

\begin{tabular}{lllll}
\hline Organ/tissue & Control & Upper & Middle & Lower \\
\hline Liver & $83 . \pm 2.0^{a}$ & $78.6 \pm 4.1^{a}$ & $272.3 \pm 2.3^{c}$ & $361 \pm 5.6$ \\
Gills & $73.0 \pm 1.5^{a}$ & $75.1 \pm 3.3^{a}$ & $178.0 \pm 10.8^{c}$ & $182 \pm 4.3^{c}$ \\
Muscle & $46.1 \pm 1.9^{a}$ & $48.3 \pm 2.5^{a}$ & $138 \pm 9.3^{a}$ & $153 . \pm 5.0^{c}$ \\
Brain & $21.4 \pm 0.5^{a}$ & $23.0 \pm 1.1^{a}$ & $47.47 \pm 5.1^{c}$ & $52.3 \pm 2.1^{c}$ \\
Kidney & $64.0 \pm 1.7^{a}$ & $62.1 \pm 3.2^{a}$ & $146.0 \pm 11.3^{c}$ & $167.8 \pm 6.6^{c}$ \\
Intestinal tract & $72.0 \pm 1.3^{a}$ & $76.3 \pm 5.4^{a}$ & $183.4 \pm 1.7^{c}$ & $203 \pm 12^{a}$ \\
Heart & $93.4 \pm 1.5^{a}$ & $89.6 \pm 3.7^{a}$ & $205 \pm 1.9^{c}$ & $242 \pm 6.6^{c}$ \\
\hline
\end{tabular}

Values are means $\pm \mathrm{SE}$ of determination from five fishes. Means with different superscript letters in the same row are significantly different from each other at $\mathrm{P}<0.05$.

\section{References}

[1] Achuba F. I.2002, Superoxide dismutase and lipid peroxidation level in fish from the Ethiope River in Southern Nigeria. Bull Environ Contam Toxicol 69(6):892-889.

[2] Achuba F.I. and Osakwe S.A.2003, Petroleum induced free radical toxicity in Africa catfish (Clarias gariepirus). Fish Physiol Biochem. 29(29):97-103.

[3] Aebi, H. 1974. Catalase. In methods of enzymatic analysis (Brgmeyer, H.U (Ed) Academic Press, New York. pp. 673 684.

[4] Aksnes, A. and Njaa, R.L. 1981. Catalase, glutathione peroxidase and superoxide dismutase in different fish species. Comp. Biochem, Physiol, 69B: 893896.

[5] Agada E.G.O.1994, heavy metal concentration in selected fish fauna of Warri River and its tributaries PhD Thesis, University of Benin Nigeria. 
[6] Afonso L.O. Basun, B., Nakano K., Delvin R. H and Iwama G. K.2003.sex-selected differences in organismal and cellular stress response in juvenile salmon exposed to treated bleached kraft mill effluent. Fish Physiol Biochem 29: 173 - 179.

[7] Atuma S. O. and Egborge ABM 1986 Insecticide and metal in Nigerian surface water- Warri River. Inter J. Environ Studies. 27:139-142.

[8] Bainy A.C.D. Saito E., Cavalho P.S. M and Junqueria V.B.C 1996. Oxidative stress in gill, erythrocytes, liver and kidney of Nile tilapia (Oreochromis niloticus) from polluted site. Aquatic Toxicol (Amst) 34:151 - 162.

[9] Bailey G.,HendrickJ. and Dashwood R.1992. Anticarcinogenesis in fish. Mutat Res 267:243-250.

[10] Bailey G.S., Williams D.E. and Hendrick J.D. 1996. Fish model for environmental carcinogenessis: the rainbow trout. Environ Health Perspect 104 (suppl. 1): 5-21.

[11] Barton B. A. and Iwama G. K.1991. Physiological changes in fish from stress in aquaculture with the emphasis on the response and effects of corticosteroids. Ann Rev. Fish Dis 1:326.

[12] Beers, R.F. and Sizer, I.W. 1952. A spectrophotometric method for measuring the breakdown of hydrogen peroxide by catalas. J Biol. Chem. 195: 133 - 104.

[13] Chukwogo E.I. (1990) Effects of industrial activities in Warri area of the surface water quality. Msc Thesis, University of Benin, Nigeria.

[14] Cohen, G., Dembiec, D. and Marcus, J. (1970) Measurement of catalase activity in tissue extracts. Analyt. Biochem. 34: 30 -38 .

[15] Conway J.G., Tomaszewski K.E. Olso M.J., Cattley R.C., Marsman D. S. and Popp J. A.1989. Relationship of oxidative damage to the hepatocarcinogenicity of the peroxisome proliferators di (2-ethylhexyl) pthalate and Wy-14,643. Carcinogenesis 10:513-519.

[16] Crapo. J.D. Mc Cord. J.M. and Fridovich, I. 1978. Preparation and assay of superoxide dismutases. Meth. Enzyme 53: $328-$ 393.

[17] DiGuilio R.T., Washburn P.C, Wenneing R.J, Winstor G.W. and Jewell C.S 1989 Biochemical responses in aquatic animals: a review of determinants of oxidative stress. Environ Toxicol Chem. 8:1103-1123.

[18] DiGuilio R.T, Habig C. and Gallagher E.P. 1993. Effects of black rock harbor sediment on indices of biotransformation, oxidative stress and DNA integrity in channel catfish. Aquatic Toxicol 26:1-22.

[19] Downs C.A, Shigenaka G., Fauth J.E, Robinson C.E. and Huang A 2002 Cellular physiological assessment of Bivalves after chronic exposure to spilled Exxon Valdez crude oil using a novel molecular diagnostic biotechnology. Environ Sci Technol 36 (13) 2987-2993.

[20] Egborge A.B.M, and Benka-Coka J. 1986. Water quality index. Application in Warri River Environ Pollut 12:27-40.

[21] Egborge A.B.M, 1994. Water Pollution in Nigeria (I) Biodiversity and Chemistry of Warri River. Ben Miller Publishers Warri.

[22] Egborge A.B.M, 1991. Industrialisation and heavy metal pollution in Warri River. $32^{\text {nd }}$ Inangural Lecture. University of Benin City, Nigeria 22pp.

[23] Egborge A.B.M and Tawari P.L. 1987. The Rotifera of Warri River, Nigeria. J. Plankt Res 9:1-3.

[24] Ezemonye LIN 1992 Heavy metals concentration in water, sediment and selected fish fauna in the Warri River and its tributaries. Ph.D Thesis, University of Benin.

[25] Fatima M, Ahmad I, Sayeed I Athar M and Raisuddins 2000. Pollutant- induced over-activation of phaqucytes is concomitantly associated with peroxidative damage in fish tissues. Aquatic Toxicol 49:243- 250.

[26] Gutteridge, J.M.C. and Wilkins S. 1982. Copper dependent hydroxyl radical damage to ascorbic acid. Fed. European Society Letters. 137: $327-327$.

[27] Hai D.Q, Varga S.I. and Matkovics B.D. 1997 Organs phosphate effects on antioxidants system of carp (Cyprinus capis) and catfish (Ictalurus nebulosus) Comp Biochem Physiol C. Pharmacol Toxicol Endocrinol. 117: 83-88.

[28] Hasspieler B.M, Behar J.V, Carlson D.B, Watson D.E. and DiGiulio R.T. 1994 Susceptibility of Channel catfish (Ictalurus punctatus) and brown bullhead (Ameruirus nebulosus) to oxidative stress: a comparative study. Aquatic Toxicol. 28:53-64.

[29] Hunter, F.E., Gebicki, J.M., Hoffstein, P.E., Weinstein, J. and Scott A. 1963 Swelling and Iysis of rat liver mitochondria induced by ferrous ion. J. Biol. Chem. 238, 847851.

[30] Ikomi R.B. 1993. Studies on the ecology of the clupeid (Pellonula leonensis Reagan 1917) in the River Warri (NigerDelta Nigeria) Acta Hydrobiol 35:381-398.

[31] Ikomi R.B. 1995 Studies on the growth pattern, feeding habits and reproductive characteristics of the Mornysid Brienomyrus longianalis (Boulenger 1901) in the Upper Warri River Nigeria. Fisheries Res 26:187-198.

[32] Ikomi R.B and Emuh C.T 2000 studies of the status of the physico- chemical hydrology of Upper Warri River (Niger Delta Nigeria) Nigeria J. Sci Environ 2:75-86.

[33] Isamah G.K and Asgba S.O. 2004. A Comparative study on the archives of zanthine oxidase and aldehyde oxidase in different fish species from two rivers in the Western Niger-Delta. Environ Monitor Assessm 91 (1-3) 293-300.

[34] Isamah G.K, Asagba S.O. and Coker H.A (2000). Comparative evaluation of the levels of some antioxidant enzymes and lipid peroxidatoin in different fish species in two rivers in Western Nigeria. Bull Environ Contam Toxicol. 65 (3): 351- 356.

[35] Iwama, G.K, Vijayanm M.M, Forsyth R.B and Ackjerman, P.A 1999. Heat Shock proteins and physiological stress in fish. Am Zool. 39:901- 909.

[36] Izokun-Etiobhio, B.O, Oraedu A.C.I,and Ugochkwu E.N. 1990. A Comparative Study of Superoxide dismutase in various animal species. Comp Biochem Physiol. 95:521-523.

[37] Kakulu, S.E, Osibanjo, O. and Ajayi S.O. 1987 Trace Metals content of fish and shell fishes of the Niger-Delta Area of Nigeria. Environ Int. 13:247-251.

[38] Livingstone, D. 2001 Contaminant-stimulated reactive oxygen species production and oxidative damage in aquatic organisms Mar Pollut Bull 42:656-666. 
[39] Misra, H.P. and Fridovich, I. 1972. The role of superoxide ion in the auto- oxidation of epinephrine and a simple assay for superoxide dismutase, J. Biol. Chem. 247: 3170-3175.

[40] Munkittrick, K.R, McMaster, M.E, McCarthy L.H Servas, M.R, and Van Der Kraak G.J 1998. An Ovberview of recent studies on the potential of pulp-mill effluents to alter reproductive parameters in fish. J Toxicol Environ Health Part B1:347-317.

[41] Munkittrick, K.R, McMaster, M.E, Van Der Kraak G.J, Portt C, Gibbons, W.N., Fawell A, and Gary M. 2000 Development of methods for effects-driven cumulative effects assessment using fish pollutions: Moose River project. Published by the society of Environmental Toxicology and Chemistry (SETAC) $256 \mathrm{pp}$.

[42] Opute F.I 1991 A checklist of the freshwater, brackish and Marine phytoplankton of the Warri / Forcades estuaries of Southern Nigeria. Nigerian J Bot 208:101-109.

[43] Otto, D.M.E and Moon T.W. 1996 Phase I and II enzymes and antioxidant responses in different tissues of brown bullheads from relatively polluted and non-polluted systems. Arch Environ Contam Toxicol 31:141-147.
[44] Parihar, M.S. and Dubey A.K. 1995. Lipid peroxidation and ascorbic acid status in respiratory organs of Male and Female freshwater catfish Heteropneustes fossilis exposed to temperature increase. Comp Biochem Physiol C 112: 309-313.

[45] Rodriquez-Ariza, A, Peinado J, Pueyo C. and Lopez - Barea J. 1993. Biochemical indicators of oxidative stress in fish from polluted littoral areas. Can J. Fish Aquat Sci 50:2568-2573.

[46] Smirnoff, N. 1993. the role of active oxygen in response to water deficit and desiccation. New Phytol 125:27-58.

[47] Tetsola, E.A. and Egborge, A.B.M 1991. Salinity and seasonality of fishes in Warri River Nigeria. Tropical Ecology 32:186-196

[48] Thomas, P and Wofford H.W. 1993. Effects of cadmium and aroclor 1254 on lipid peroxidation, glutathione peroxidase activity, and selected antioxiadants in Atlantic Croaker tissues. Aquatic Toxicol 27:159-178.

[49] Voet D and Voet J.G. 1990 Biochemistry. John Willey and sons, New York pp 10-11 